\title{
Synthesis of some natural sulphonamide derivatives as carbonic anhydrase inhibitors
}

\author{
Taner Gokcen ${ }^{* 1,6}$, Melike $\mathrm{Al}^{2}$, Meryem Topal ${ }^{3,4}$, Ilhami Gulcin ${ }^{4,5}$, \\ Turan Ozturk ${ }^{1,6}$ and Ahmet C. Goren ${ }^{1}$ \\ ${ }^{I}$ TUBITAK UME, Chemistry Group Laboratories, P.O. Box:54, 41470, Kocaeli, Türkiye \\ ${ }^{2}$ Beuth University of Applied Sciences, Faculty II of Pharma and Chemical Engineering, Berlin, \\ Germany \\ ${ }^{3}$ Gumushane University, Vocational School of Health Services, Department of Medical Services and \\ Techniques, Gumushane, Türkiye \\ ${ }^{4}$ Ataturk University, Faculty of Science, Department of Chemistry, Erzurum, Türkiye \\ ${ }^{5}$ Programming of Diseases Research Chair, Zoology Department, College of Science, King Saud \\ University, Riyadh, Saudi Arabia \\ ${ }^{6}$ Istanbul Technical University, Faculty of Science, Department of Organic Chemistry, \\ Istanbul, Türkiye
}

(Received April 10, 2016; Revised October 5, 2016; Accepted October 28, 2016)

\begin{abstract}
Carbonic anhydrase inhibitors are both in clinical use as antiglaucoma, diuretics, antiepileptics and management of altitude sickness, and under investigation as anticancer, anticonvulsant and antiobesity agents. Sulphonamides have been known for decades as carbonic anhydrase inhibitors and are in clinical use. Sulphonamide derivatives of $p$-hydroxybenzoic acid and 3,4,5-trihydroxybenzoic acid (gallic acid) were synthesized and their inhibition values over hCA I and hCA II isozymes, purified from human erythrocyte cells by Sepharose-4B-L-tyrosine-sulphanilamide, were determined. Compounds synthesized showed efficient carbonic anhydrase inhibition activity at low nM levels.
\end{abstract}

Keywords: Carbonic anhydrase inhibitor; sulphonamides; $p$-hydroxybenzoic acid; 3,4,5-trihydroxybenzoic acid (gallic acid). ( $) 2017$ ACG Publications. All rights reserved.

\section{Introduction}

Although since the first synthesis as a chemotherapeutic agent in the early 1930s, sulphonamides have been withdrawing increasing interest, ${ }^{1}$ they found limited applications on human therapy, possibly due to the advancements in antibiotic area and some of their toxicological effects. ${ }^{2-3}$ As they are relatively cheap and effective toward many bacterial infections, they are widely used as veterinary drugs. Moreover, its active side " $-\mathrm{SO}_{2} \mathrm{NH}_{2}$ " has been incorporated into various actively used drugs on human therapy. ${ }^{4-7}$

\footnotetext{
${ }^{*}$ Corresponding author: E-mail: taner.gokcen@ tubitak.gov.tr Tel: +902626795000 Fax: +902626795001
} 
Conversion of carbon dioxide $\left(\mathrm{CO}_{2}\right)$ and water $\left(\mathrm{H}_{2} \mathrm{O}\right)$ into bicarbonate $\left(\mathrm{HCO}_{3}^{-}\right)$and proton $\left(\mathrm{H}^{+}\right)$is a simple reaction catalyzed by a super family of zinc containing metallo enzymes, called carbonic anhydrases (CAs, EC 4.2.1.1). ${ }^{8-11}$ Carbonic anhydrases, having medium-sized molecular weight, are ubiquitous metallo enzymes present either in prokaryotes or eukaryotes and, so far, six genetically distinct families have been acknowledged. ${ }^{12-14}$ There are fifteen human carbonic anhydrases, belonging to $\alpha$-class, have been recognized. They differ from each other with their kinetic properties, inhibition and their expression in various tissues and cellular localization, such that CAs I, II, III, VII, and XIII are cytosolic, IV, IX, XII, and XIV are associated with the cell membrane, VA and VB are located in the mitocondria, VI, secreted in saliva and milk, show enzymatic activity, and VIII, X and XI are CA-related proteins (CARPs) without any catalytic activity. ${ }^{15-18}$

Carbonic anhydrases play crucial roles in a variety of physiological processes such as electrolyte secretion in a variety of tissues and organs, calcification, biosynthetic reactions (lipogenesis, ureagenesis, and gluconeogenesis are among them), $\mathrm{pH}$ and $\mathrm{CO}_{2}$ homeostasis, bone resorption and tumorigenicity, and many others. ${ }^{21-23}$ Inhibition of carbonic anhydrases are becoming increasingly popular as a research subject, which is due to their abnormal levels associated with various diseases such as glaucoma, cancer, osteoporosis and some neurological disorders. ${ }^{15}$

Sulphonamides, phenols and coumarins are three examples of CA inhibitors acting through different mechanisms, (i) displacing zinc-bound water/hydroxide ion by coordination to the $\mathrm{Zn}$ (II) ion in the enzyme active side and leading to a tetrahedral geometry, or by addition to the metal coordination sphere and leading to a trigonal bipyramidal geometry, (ii) hooking up to the $\mathrm{Zn}$ (II)bound water/hydroxide ion and (iii) by obstructing the active site cavity of the enzyme, respectively. ${ }^{17,22}$

Primary sulphonamides are well known carbonic anhydrase inhibitors, first examples of which were derivatives of clinically used ones such as acetazolamide (AAZ), ethoxzolamide (EZA) and indisulfam (IND) (Figure 1.). ${ }^{23}$ Today, it is acknowledged that when designing therapeutic agents, selective inhibition of CAs or, at least, organ specific targeting is the main goal. ${ }^{15}$ However, since there are at least fifteen carbonic anhydrase isozyme in human, their spread localization in many tissues and organs, and none of the currently sulphonamide or sulfamate CA inhibitors in clinical use is selective for a specific isozyme is a high barrier to achieve. ${ }^{24,25}$ Although, it was believed that amine group of sulphonamide should be primary to act as carbonic anhydrase inhibitor, recent studies indicated that secondary and even tertiary sulphonamides can act as affective carbonic anhydrase inhibitors and they can be selective. ${ }^{26-38}$<smiles>CC(=O)Nc1nnc(S(N)(=O)=O)s1</smiles>

AAZ<smiles>CCOc1ccc2nc(S(N)(=O)=O)sc2c1</smiles>

EZA<smiles>NS(=O)(=O)c1ccc(S(=O)(=O)Nc2cccc3c(Cl)c[nH]c23)cc1</smiles>

IND

Figure 1. Some sulphonamides on clinical use, AAZ, EZA and IND

The natural phenolic acids, gallic (3,4,5-trihydroxybenzoic) acid and $p$-hydroxybenzoic acid, found in many plants and used as preservatives in food, possess antibacterial, anticarcinogenic, antioxidant, antifungal and antimutagenic activities, and cytotoxicity toward tumor cells. ${ }^{29-31}$ Innocenti 
et al. showed that $p$-hydroxybenzoic acid had better inhibition properties on hCA I and hCA II compare with the natural product polyphenols and phenolic acids. ${ }^{22}$ In this study, we reported secondary sulphonamides synthesized from $p$-hydroxybenzoic acid and 3,4,5-trihydroxybenzoic acid (Scheme 1), and investigated synergy of sulphonamides and polyphenols as carbonic anhydrase inhibitors on the hCA I and hCAII isozymes purified from human erythrocyte cells by Sepharose-4BL-tyrosine-sulphanilamide.

\section{Experimental}

\subsection{Materials and apparatus}

All starting materials and reagents were purchased from commercial suppliers. Progress of the reactions were monitored by TLC, using silica gel-60 F254 plates with detection by short wave UV fluorescence $(\lambda=254 \mathrm{~nm})$ and staining with ceric sulphate. Silica gel flash chromatography was performed using silica gel $60 \AA$ (230-400 mesh). Purity of compounds determined by HPLC at 270 nm. ${ }^{1} \mathrm{H}$ and ${ }^{13} \mathrm{C}$ NMR spectra were recorded on a Varian $600 \mathrm{MHz}$ spectrometer at $25{ }^{\circ} \mathrm{C}$. Chemical shifts for ${ }^{1} \mathrm{H}$ and ${ }^{13} \mathrm{C}$ NMR spectra obtained in DMSO- $\mathrm{d}_{6}$ were reported in ppm relative to the residual solvent proton $(\delta=2.50 \mathrm{ppm})$ and carbon $(\delta=39.52 \mathrm{ppm})$ signals, respectively. Multiplicity was indicated as follows: $\mathrm{s}$ (singlet); $\mathrm{d}$ (doublet); $\mathrm{m}$ (multiplet). Coupling constants were reported in hertz $(\mathrm{Hz})$. High-resolution mass spectra (HRMS) were recorded on BrukerMicrOTOF-Q at positive electro spray ionization (ESI+) mode. ${ }^{1} \mathrm{H}$ and ${ }^{13} \mathrm{C}$ NMR, and HRMS spectra of compounds are provided in Supporting Information.

Table 1. hCA I and hCA II inhibiton values of the compounds

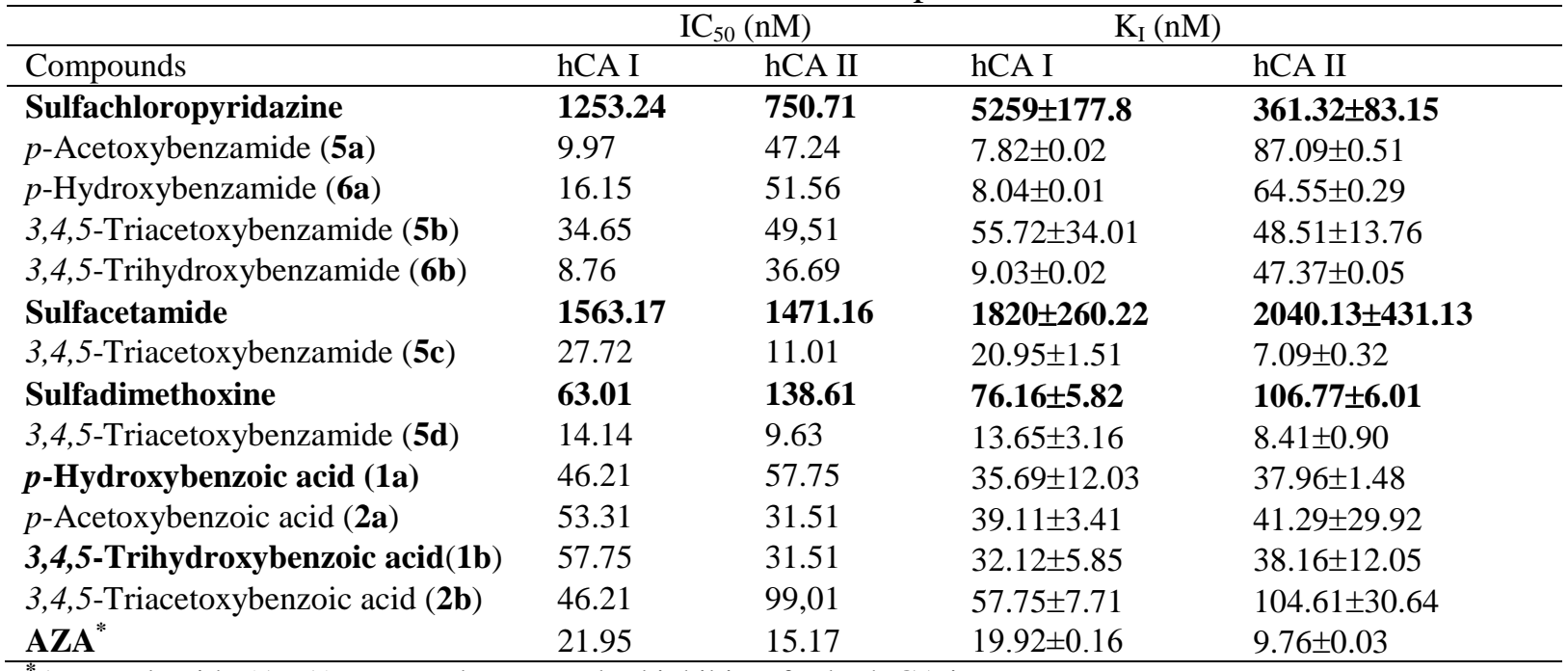

"Acetazolamide (AZA) was used as a standard inhibitor for both CA isoenzyme

2.2. General procedure for acetyl protection of hydroxyl groups on phenolic acids (2): To a stirred mixture of hydroxyl substituted benzoic acid $1(20 \mathrm{mmol})$ and acetic anhydride $(120 \mathrm{mmol})$ in round bottom flask was added a few drops of concentrated $\mathrm{H}_{2} \mathrm{SO}_{4}$, and the after all the solid was dissolved, the mixture was left stirring for an hour. Then water $(100 \mathrm{~mL})$ was added to remove any excess acetic anhydride left and the stirring was continued for further $2.5 \mathrm{~h}$. A white crystalline product was filtered and washed with water $(2 \times 50 \mathrm{~mL})$. The solid product was dried on filter by air suction for 10 minutes and then high vacuum for overnight.

2.3. General procedure for preparing acyl chlorides (3): A mixture of acetyl protected phenolic acid $\mathbf{2}$ (20 mmol) and thionyl chloride $(300 \mathrm{mmol})$ was refluxed for 5 hours. Excess of thionyl chloride was 
distilled and the remaining crude product was diluted with acetone $(20 \mathrm{~mL})$ of acetone and used for the next step without any further purification.

2.4. General procedure for the synthesis of $N$-(sulfonamide)-acetoxybenzamide (5): Acyl chloride 3 $(20 \mathrm{mmol})$ in acetone $20 \mathrm{~mL}$ was added dropwise to a solution of sulphonamide $(20 \mathrm{mmol})$ and pyridine $(20 \mathrm{mmol})$ in acetone $(50 \mathrm{~mL})$ at $0{ }^{\circ} \mathrm{C}$. Then, the reaction mixture was stirred at room temperature for overnight. When a precipitate was obtained, it was filtered. Otherwise the solvent was evaporated under reduced pressure and the crude product was purified by recrystallization from ethanol or flash column chromatography using ethyl acetate/hexane (1:1) as a mobile phase.

2.5. General procedure for deacetylation of $\mathrm{N}$-(sulfonamide)-acetoxybenzamide (6): $\mathrm{N}$-(sulfonamide)acetoxybenzamide 5 was added to a solution of tetrahydrofuran $(10 \mathrm{~mL})$, methanol $(10 \mathrm{~mL})$ and concentrated hydrochloric acid $(5 \mathrm{~mL})$. The mixture was stirred at $60{ }^{\circ} \mathrm{C}$ for one hour. The solvent was evaporated under reduced pressure and the crude product was purified by recrystallization from ethanol or flash column chromatography using ethyl acetate/hexane (1:1) as a mobile phase.

p-Acetoxybenzoic acid (2a): Yield 90\%. ${ }^{1} \mathrm{H}$ NMR (DMSO-d 6 , $\left.600 \mathrm{MHz}\right) \delta(\mathrm{ppm}): 7.99(\mathrm{~d}, J=8.6$ $2 \mathrm{H}), 7.26(\mathrm{~d}, J=8.62 \mathrm{H}), 2.28(\mathrm{~s}, 3 \mathrm{H})$.

3,4,5-Triacetoxybenzoic acid $(\mathbf{2 b})$ : Yield 85\%. ${ }^{1} \mathrm{H}$ NMR (DMSO-d $\left.{ }_{6}, 600 \mathrm{MHz}\right) \delta(\mathrm{ppm}): 7.72(\mathrm{~s}, 2 \mathrm{H})$, $2.30(\mathrm{~s}, 3 \mathrm{H}), 2.27(\mathrm{~s}, 6 \mathrm{H})$.

$N$-(Sulfachloropyridazine)-p-acetoxybenzamide (5a): Yellowish powder, yield 45\%, m.p. $235-236{ }^{\circ} \mathrm{C}$. ${ }^{1} \mathrm{H}$ NMR (600 MHz, DMSO-d 6 ) $\delta(\mathrm{ppm}):{ }^{1} \mathrm{H}$ NMR $(600 \mathrm{MHz}$, DMSO-d 6 ) $\delta 10.63(\mathrm{~s}, 1 \mathrm{H}), 8.00(\mathrm{~d}, J=$ $8.7 \mathrm{~Hz}, 2 \mathrm{H}), 7.97(\mathrm{~d}, J=8.8 \mathrm{~Hz}, 2 \mathrm{H}), 7.91(\mathrm{~d}, J=8.8 \mathrm{~Hz}, 2 \mathrm{H}), 7.78(\mathrm{~d}, J=9.5 \mathrm{~Hz}, 1 \mathrm{H}), 7.57$ (broad, $1 \mathrm{H}), 7.31(\mathrm{~d}, J=8.7 \mathrm{~Hz}, 2 \mathrm{H}), 2.31(\mathrm{~s}, 3 \mathrm{H}) .{ }^{13} \mathrm{C}$ NMR $\left(150 \mathrm{MHz}, \mathrm{DMSO}-\mathrm{d}_{6}\right) \delta(\mathrm{ppm}): 168.97,165.30$, 154.27, 153.22, 143.30, 131.95, 131.64, 129.42, 128.06, 122.60, 122.03, 119.85, 20.90. HRMS $\left(\mathrm{ESI}^{+}\right)$: $m / z$ calculated for $\mathrm{C}_{19} \mathrm{H}_{15} \mathrm{ClN}_{4} \mathrm{O}_{5} \mathrm{~S}_{1} \mathrm{Na}_{1}\left[\mathrm{M}+\mathrm{Na}^{+}\right]: 469.0344$, found 469.0342 .

$N$-(Sulfachloropyridazine)-3,4,5-triacetoxybenzamide (5b): Yellowish powder, yield 35\%, m.p. 242$243{ }^{\circ} \mathrm{C} .{ }^{1} \mathrm{H}$ NMR (600 MHz, DMSO-d $\left.{ }_{6}\right) \delta(\mathrm{ppm}): 10.67(\mathrm{~s}, 1 \mathrm{H}), 7.93-7.89(\mathrm{~m}, 4 \mathrm{H}), 7.80(\mathrm{~s}, 2 \mathrm{H}), 7.76$ $(\mathrm{d}, J=9.5 \mathrm{~Hz}, 1 \mathrm{H}), 7.50($ broad, $1 \mathrm{H}), 2.32(\mathrm{~s}, 3 \mathrm{H}), 2.30(\mathrm{~s}, 6 \mathrm{H}) .{ }^{13} \mathrm{C}$ NMR $(150 \mathrm{MHz}$, DMSO-d 6 ) $\delta$ (ppm): 168.84, 168.12, 167.06, 163.76, 154.32, 150.50, 145.50, 143.24, 139.16, 137.71, 132.45, $128.10,120.83,120.15,119.99,20.39,19.94$. HRMS $\left(\mathrm{ESI}^{+}\right): \mathrm{m} / \mathrm{z}$ calculated for $\mathrm{C}_{23} \mathrm{H}_{20} \mathrm{ClN}_{4} \mathrm{O}_{9} \mathrm{~S}_{1}$ $\left[\mathrm{M}+\mathrm{H}^{+}\right]: 563.0634$, found 563.0640 .

$N$-(Sulfacetamide)-3,4,5-triacetoxybenzamide (5c): Off white powder, yield $43 \%$, m.p. $220-221{ }^{\circ} \mathrm{C}{ }^{1} \mathrm{H}$ NMR (600 MHz, DMSO-d $\left.{ }_{6}\right) \delta(\mathrm{ppm}): 12.01(\mathrm{~s}, 1 \mathrm{H}), 10.72(\mathrm{~s}, 1 \mathrm{H}), 7.96(\mathrm{~d}, J=8.9 \mathrm{~Hz}, 2 \mathrm{H}), 7.89$ (d, $J$ $=8.9 \mathrm{~Hz}, 2 \mathrm{H}), 7.82(\mathrm{~s}, 2 \mathrm{H}), 2.33(\mathrm{~s}, 3 \mathrm{H}), 2.31(\mathrm{~s}, 6 \mathrm{H}), 1.90(\mathrm{~s}, 3 \mathrm{H}) .{ }^{13} \mathrm{C}$ NMR $\left(150 \mathrm{MHz}\right.$, DMSO $\left.-d_{6}\right) \delta$ (ppm): 169.14, 168.46, 167.39, 164.14, 143.79, 143.61 , 138.10, 134.17, 132.78, 129.19, 121.23, $120.33,23.65,20.77,20.32$. HRMS $\left(\mathrm{ESI}^{+}\right): \mathrm{m} / z$ calculated for $\mathrm{C}_{21} \mathrm{H}_{21} \mathrm{~N}_{2} \mathrm{O}_{10} \mathrm{~S}_{1}\left[\mathrm{M}+\mathrm{H}^{+}\right]: 493.0911$, found 493.0927.

$N$-(Sulfadimethoxine)-3,4,5-triacetoxybenzamide (5d): White powder, yield 57\%, m.p. $197-198{ }^{\circ} \mathrm{C} .{ }^{1} \mathrm{H}$ NMR (600 MHz, DMSO-d $\left.{ }_{6}\right) \delta(\mathrm{ppm}): 10.71(\mathrm{~s}, 1 \mathrm{H}), 7.98-7.93(\mathrm{~m}, 4 \mathrm{H}), 7.82(\mathrm{~s}, 2 \mathrm{H}), 5.96(\mathrm{~s}, 1 \mathrm{H})$, $3.80(\mathrm{~s}, 3 \mathrm{H}), 3.77(\mathrm{~s}, 3 \mathrm{H}), 2.35(\mathrm{~s}, 3 \mathrm{H}), 2.33(\mathrm{~s}, 6 \mathrm{H}) .{ }^{13} \mathrm{C}$ NMR $\left(150 \mathrm{MHz}, \mathrm{DMSO}-\mathrm{d}_{6}\right) \delta(\mathrm{ppm}): 172.11$, 168.42 , 167.37, 164.69, 164.13, 160.31, 143.59, 143.48, 138.07, 134.78, 132.80, 128.79, 121.18, 120.47, 85.02, 54.97, 54.24, 20.72, 20.28. HRMS $\left(\right.$ ESI $\left.^{+}\right): m / z$ calculated for $\mathrm{C}_{25} \mathrm{H}_{25} \mathrm{~N}_{4} \mathrm{O}_{11} \mathrm{~S}_{1}\left[\mathrm{M}+\mathrm{H}^{+}\right]$: 589.1235 , found 589.1235 .

$N$-(Sulfachloropyridazine)-p-hydroxybenzamide (6a): Yellowish powder, yield 35\%, m.p. 161-162 ${ }^{\circ} \mathrm{C} .{ }^{1} \mathrm{H}$ NMR (600 MHz, DMSO-d 6 ) $\delta(\mathrm{ppm}):{ }^{1} \mathrm{H}$ NMR (600 MHz, dmso) $\delta 10.34(\mathrm{~s}, 1 \mathrm{H}), 10.18(\mathrm{~s}$, $1 \mathrm{H}), 7.96(\mathrm{~d}, J=8.8 \mathrm{~Hz}, 2 \mathrm{H}), 7.89-7.84(\mathrm{~m}, 4 \mathrm{H}), 7.78(\mathrm{~d}, J=9.6 \mathrm{~Hz}, 1 \mathrm{H}), 7.52$ (broad, $1 \mathrm{H}), 6.87(\mathrm{~d}, J$ $=8.6 \mathrm{~Hz}, 2 \mathrm{H}) .{ }^{13} \mathrm{C}$ NMR $\left(150 \mathrm{MHz}, \mathrm{DMSO}-\mathrm{d}_{6}\right) \delta(\mathrm{ppm}): 165.50,160.91,154.22,143.79,132.36$, 
129.95, 128.02, 124.78, 119.67, 115.01. HRMS $\left(\mathrm{ESI}^{+}\right): \mathrm{m} / z$ calculated for $\mathrm{C}_{17} \mathrm{H}_{13} \mathrm{ClN}_{4} \mathrm{O}_{4} \mathrm{~S}_{1} \mathrm{Na}$ $\left[\mathrm{M}+\mathrm{Na}^{+}\right]: 427.0238$, found 427.0237 .

$N$-(Sulfachloropyridazine)-3,4,5-trihydroxybenzamide $(\boldsymbol{6} \boldsymbol{b})$ : Yellowish powder, yield 40\%, m.p. 175$176{ }^{\circ} \mathrm{C} .{ }^{1} \mathrm{H}$ NMR $\left(600 \mathrm{MHz}, \mathrm{DMSO}-\mathrm{d}_{6}\right) \delta 10.27(\mathrm{~s}, 1 \mathrm{H}), 8.90(\mathrm{~s}, 1 \mathrm{H}), 7.94(\mathrm{~d}, J=8.8 \mathrm{~Hz}, 2 \mathrm{H}), 7.86(\mathrm{~d}$, $J=8.3 \mathrm{~Hz}, 2 \mathrm{H}), 7.78(\mathrm{~d}, J=9.4 \mathrm{~Hz}, 1 \mathrm{H}), 6.95(\mathrm{~s}, 2 \mathrm{H}) .{ }^{13} \mathrm{C}$ NMR $\left(150 \mathrm{MHz}\right.$, DMSO-d $\left.{ }_{6}\right) \delta 166.37$, 154.62, 146.00, 145.13, 137.65, 131.36, 128.40, 124.69, 120.00, 119.50, 107.80. HRMS $\left(\mathrm{ESI}^{+}\right): \mathrm{m} / \mathrm{z}$ calculated for $\mathrm{C}_{17} \mathrm{H}_{13} \mathrm{ClN}_{4} \mathrm{O}_{6} \mathrm{~S}_{1} \mathrm{Na}\left[\mathrm{M}+\mathrm{Na}^{+}\right]$: 459.0137, found 459.0134.

\subsection{Biochemistry}

Both CA isoenzyme (hCA I and II) were purified by Sepharose-4B-L-tyrosine-sulphanilamide affinity chromatography in a single purification step. ${ }^{37}$ The column material Sepharose-4B-L-tyrosinesulphanilamide was prepared according to a reported method. ${ }^{17}$ Then, the homogenate solution acidity was adjusted to 8.7 with a $\mathrm{pH}$-meter using solid Tris and the supernatant was transferred to the Sepharose-4B-L tyrosine-sulphanilamide affinity column. ${ }^{38}$ The proteins obtained from column was spectrophotometrically determined at $280 \mathrm{~nm}$. The purity of the isozymes was determined by sodium dodecyl sulphate-polyacrylamide gel electrophoresis (SDS-PAGE), where a single band was observed for each isozyme. ${ }^{41}$ In this application, the imaging method was performed out in $10 \%$ and $3 \%$ acrylamide for the running and the stacking gel, respectively, with $0.1 \%$ SDS. $^{42}$

Activities of the CA isozymes were determined applying the method reported by Verpoorte et al (1967). ${ }^{43}$ Briefly, the absorbance, changing at $348 \mathrm{~nm}$ for $p$-nitrophenylacetate (NPA) to $p$ nitrophenolate (NP), was recorded over a $3 \mathrm{~min}$ period at the room temperature, using a spectrophotometer (Shimadzu, UV-VIS Spectrophotometer, UVmini-1240, Kyoto, Japan). The protein was measured quantitatively at $595 \mathrm{~nm}$ during the purification steps according to the Bradford method. ${ }^{44}$ Bovine serum albumin (BSA) was used as a standard protein. ${ }^{45}$ For determining the inhibition effect of each sulphonamide derivative, an activity (\%)-[Sulphonamide] graph was plotted. To determine $\mathrm{K}_{\mathrm{i}}$ values, three different concentrations of sulphonamide derivatives were tested. In these experiments, NPA was used as a substrate at five different concentrations and Lineweaver-Burk curves were plotted.

\section{Results and discussion}

Polyphenols are secondary metabolites ubiquitously occurring in all higher plants and are found largely in foods and beverages, such as fruits, vegetables, tea and coffee, which play multiple essential roles in plant physiology and have healthy effects on human organism associated to their anti-oxidant and metal chelator properties. In some cases it has been reported by some clinical and epidemiological studies that long term consumption of diets rich in plants comprise polyphenols offer protection against cancer, diabetes, cardiovascular and neurodegenerative diseases, hypertension and aging. ${ }^{39,40}$ Synthesis of the sulphonamide derivatives $\mathbf{5 a - d}, \mathbf{6 a}, \mathbf{b}$ were started with acetyl protection of hydroxyl groups of the phenolic acids 1a,b through an acid catalyzed reaction of acetic anhydride to obtain $\mathbf{2 a}, \mathbf{b}{ }^{32}$ Conversion of the acid groups of $\mathbf{2 a}, \mathbf{b}$ using thionyl chloride to the acid chlorides $\mathbf{3 a}, \mathbf{b}$ was followed by addition of commercially available sulphonamides $\mathbf{4}$, which yielded the products 5a,d. ${ }^{33}$ Acetyl protection of hydroxyl groups is a common approach in pharmaceutical industry to enhance oral bioavailability and increase the therapeutic concentration of the drug in bloodstream.

These protected compounds are called pro-drugs since they are hydrolyzed to the corresponding alcohol by carboxylesterases in blood. ${ }^{34}$ The sulfachloropyridazines $\mathbf{6 a , b}$ were then obtained via deacetylation of $\mathbf{5 a}, \mathbf{b}$, applying an acid catalyzed reaction in tetrahydrofuran and methanol (Scheme 1). ${ }^{33}$ It should be noted that compounds $\mathbf{5} \mathbf{b}^{35}, \mathbf{6} \mathbf{a}^{36}$ and $\mathbf{6} \mathbf{b}^{35}$ are known compounds but no carbonic anhydrase inhibition reported before. 
<smiles>[R]NS(=O)(=O)c1ccc(N)cc1</smiles><smiles>[R]NS(=O)(=O)c1ccc(NC(=O)c2cc(NC(=O)c3cc([X])c(O)c([X])c3)ccc2S(=O)(=O)N[R])cc1</smiles>

Reagents and conditions. (i) Acetic anhydride, $\mathrm{H}_{2} \mathrm{SO}_{4}$, rt, $1 \mathrm{~h}$; (ii) $\mathrm{SOCl}_{2}, 80{ }^{\circ} \mathrm{C}, 5 \mathrm{~h}$;

(iii) sulfonamide, acetone, pyridine, $0{ }^{\circ} \mathrm{C}$ - rt, $20 \mathrm{~h}$; (iv) THF, $\mathrm{MeOH}, \mathrm{HCl}, 60^{\circ} \mathrm{C}, 1 \mathrm{~h}$.

Scheme 1. Synthesis of sulphonamide derivatives

All synthesized derivatives showed highly effective carbonic anhydrase I and II inhibition at nano molar level and better inhibiton compared to their reference sulphonamides (Table 1.), where in case of sulfachloropyridazine for hCA I it is at least hundredfold much better. Except, $\mathrm{N}$ sulfachloropyridazine-3,4,5-triacetoxybenzamide, all the compounds displayed better hCA I inhibition properties than their reference phenolic acids as well. The compound $N$-sulfachloropyridazine- $p$ acetoxybenzamide (5a) was found to be the best to inhibit cytosolic isozyme hCA I with a Ki value of $7.82 \pm 0.02 \mathrm{nM}$, where the drug in clinical use acetazolamide (AZA), had Ki value of $19.92 \pm 0.16 \mathrm{nM}$. The synergistic effect of polyphenols in combination with conventional antimicrobial agents against clinical multi-drug resistant microorganisms is discussed before ${ }^{40}$ and here in this study the synergistic effect by combination of polyphenols or naturally phenolic acids with the sulfonamides -known as privileged class of medicinal chemistry- in one molecule is bring to light. Isozyme CA II, which has no disulfide, pendant sugar and phosphate groups, is frequently investigated inhibitor as it is inexpensive, widely available and has well known structure and active site geometry. The synthesized compounds displayed high inhibition toward hCA II at nano molar level compared with reference sulphonamides. Among all the compounds, $N$-sulfacetamide-3,4,5-triacetoxybenzamide $(5 \mathrm{c})$ showed the best inhibiton of hCA II with a Ki value of $7.09 \pm 0.32 \mathrm{nM}$, where acetazolamide (AZA) had Ki value of $9.76 \pm 0.03 \mathrm{nM}$. As an overall trend it can be seen that hydroxyl substitution performed better hCA II inhibition compared to acetoxy substitution.

Three mechanisms for CA inhibition reported in the literature. As our acetyl protected compounds has no hydroxyl or primary sulphonamide groups, possible mechanism could be the 
blocking the active site cavity of the enzyme. According to the structure-activity relationship (SAR), unfortunately, it is hard to say anything on inhibiton properties related with the molecular structures of the compounds 5 and 6.

\section{Conclusion}

In conclusion, the novel sulphonamide derivatives were evaluated for their hCA I and hCA II isozymes inhibition activities. They were found to be sufficiently active at low nano molar levels. $\mathrm{N}$ sulfachloropyridazine-p-acetoxybenzamide (5a) and $N$-sulfacetamide-3,4,5-triacetoxybenzamide (5c) were found to be the best inhibitors of hCA I $\left(\mathrm{K}_{\mathrm{i}}: 7.82 \pm 0.02 \mathrm{nM}\right)$ and hCA II $\left(\mathrm{K}_{\mathrm{i}}: 7.09 \pm 0.32 \mathrm{nM}\right)$, respectively.

\section{Acknowledgements}

This article is a part of the PhD thesis of Taner Gokçen. We gratefully acknowledge financial support from the TUBITAK UME and sincere appreciation to Prof. Dr. Ramazan Altundaş for technical discussions, Gokhan Bilsel for HRMS and Ilker Un for NMR spectra.

\section{Supporting Information}

Supporting Information accompanies this paper on http://www.acgpubs.org/OC

\section{References}

[1] Kennedy, D. G.; McCracken, R. J.; Cannavan, A.; Hewitt, S. A. Use of liquid chromatography-mass spectrometry in the ananlysis of residues of antibiotics in meat and milk. J. Chromatogr. A 1998, 812(1-2), 77-98.

[2] Dal-Ho, K.; JongOh, C.; Kim, J. S.; Lee, D. W. Determination of Sulfonamides in Meat by Liquid Chromatography Coupled with Atmospheric Pressure Chemical Ionization Mass Spectrometry. Bull. Korean Chem. Soc. 2002, 23, 1590-1594.

[3] Poter, S. Confirmation of sulfonamide residues in kidney tissue by liquid chromatography-mass spectrometry. Analyst 1994, 119(12), 2753-2756.

[4] Ito, Y.; Oka, H.; Ikai, Y.; Matsumoto, H.; Miyazaki, Y.; Nagase, H. Application of ion-exchange cartridge clean-up in food analysis. V. Simultaneous determination of sulphonamide antibacterials in animal liver and kidney using high-performance liquid chromatography with ultraviolet and mass spectrometric detection. J. Chromatogr. A 2000, 898, 95-102.

[5] Abdallah, H.; Arnaudguilhem, C.; Lobinski, R.; Jaber, F. A multi-residue analysis of sulphonamides in edible animal tissues using QuEChERS extraction and HPLC-MS/MS. Anal. Methods. 2015, 7, 1549-1557.

[6] Kantiani, L.; Liorca, M.; Sanchis, J.; Farre, M.; Barcelo, D. Emerging food contaminants: a review. Anal. Bioanal. Chem., 2010, 398, 2413-2427.

[7] Abdallah, H.; Arnaudguilhem, C.; Jaber, F.; Lobinski, R. Multiresidue analysis of 22 sulfonamides and their metabolites in animal tissues using quick, easy, cheap, effective, rugged, and safe extraction and high resolution mass spectrometry (hybrid linear ion trap-Orbitrap). J. Chromatogr. A 2014, 1355, 61-72.

[8] Gülçin, İ.; Beydemir, Ş.; Büyükokuroğlu, M.E. "In vitro and in vivo effects of dantrolene on carbonic anhydrase enzyme activities". Biol. Pharm. Bull.”. Biol. Pharm. Bull. 2004, 27, 613-616.

[9] Beydemir, Ş.; Gülçin, İ. Effects of melatonin on carbonic anhydrase from human erythrocyte in vitro and from rat erythrocyte in vivo. J. Enzyme Inhib. Med. Chem. 2004, 19(2), 193-197.

[10] Marini, A.M.; Maresca, A.; Aggarwal, M.; Orlandini, E.; Nencetti, S.; Da Settimo, F.; Salerno, S.; Simorini, F.; La Motta, C.; Taliani, S.; Nuti, E.; Scozzafava, A.; McKenna, R., Rossello, A.; Supuran C.T. Tricyclic Sulfonamides Incorporating Benzothiopyrano[4,3-c]pyrazole and Pyridothiopyrano[4,3c]pyrazole Effectively Inhibit $\alpha$ - and $\beta$-Carbonic Anhydrase: X-ray Crystallography and Solution Investigations on 15 Isoforms. J. Med. Chem. 2012, 55, 9619-9629. 
[11] Supuran, C. T. Carbonic anhydrases: novel therapeutic applications for inhibitors and activators. Nature Rev. Drug Discovery 2008, 7, 168-181.

[12] Del Prete, S.; Vullo, D.; Fisher, G. M.; Andrews, K. T.; Poulsen, S. A.; Capasco, C.; Supuran, C. T. Discovery of a new family of carbonic anhydrases in the malaria pathogen Plasmodium falciparum-The $\eta$-carbonic anhydrases. Bioorg. Med. Chem. Lett. 2014, 24, 4389-4396.

[13] Çetinkaya, Y.; Göçer, H.; Göksu, S.; Gülçin, İ. Synthesis and carbonic anhydrase isoenzymes I and II inhibitory effects of novel benzylamine derivatives. J. Enzyme Inhib.Med. Chem. 2014, 29, 168-174.

[14] Güney, M.; Coşkun, A.; Topal, F.; Daştan, A.; Gülçin, İ.; Supuran C.T. Synthesis, photooxygenation reaction and carbonic anhydrase isoenzymes inhibition properties of some new benzotropone derivatives. Bioorg. Med. Chem. 2014, 22, 3537-3543.

[15] Ceruso, M.; Antel, S.; Vullo, D.; Scozzafava, A.; Supuran, C. T. Inhibition studies of new ureidosubstituted sulfonamides incorporating a GABA moiety against human carbonic anhydrase isoforms IXIV. Bioorg. Med. Chem. 2014, 22, 6768-6775.

[16] Hilvo, M.; Salzano, A. M.; Innocenti, A.; Kulomaa, M. S.; Scozzafava, A.; Scaloni, A.; Parkkila, S.; Supuran, C. T. Cloning, Expression, Post-Translational Modifications and Inhibition Studies on the Latest Mammalian Carbonic Anhydrase Isoform, CA XV. J. Med. Chem. 2009, 52, 646-654.

[17] Aksu, K.; Nar, M.; Tanc, M.;Vullo, D.; Gülçin, İ.;Göksu, S.; Tümer, F.; Supuran, C. T. Synthesis and carbonic anhydrase inhibitory properties of sulfamides structurally related to dopamine. Bioorganic \& Medicinal Chemistry 2013, 21, 2925-2931.

[18] Alterio, V. Di Fiore, A., D’Ambrosio, K., Supuran, C.T., De Simone, G. Multiple Binding Modes of Inhibitors to Carbonic Anhydrases: How to Design Specific Drugs Targeting 15 Different Isoforms? Chem. Rev. 2012, 112, 4421-4468.

[19] Gülçin, İ.; Beydemir, S. Phenolic compounds as antioxidants: carbonic anhydrase isoenzymes inhibitors. Mini Rev. Med. Chem. 2013, 13, 408-430.

[20] Innocenti, A., Gülçin, İ., Scozzafava, A., Supuran C.T. Carbonic anhydrase inhibitors. Antioxidant polyphenols effectively inhibit mammalian isoforms I-XV. Bioorganic and Medicinal Chemistry Letters 2010, 20, 5050-5053.

[21] Öztürk Sarikaya, S. B.; Topal, F.; Şentürk, M.; Gülçin, İ.; Supuran, C.T. In vitro inhibition of $\alpha$-carbonic anhydrase isozymes by some phenolic compounds Bioorg. Med. Chem. Lett. 2011, 21, 4259-4262.

[22] Innocenti, A.; Öztürk Sarıkaya, S. B.; Gülçin, İ.; Supuran C. T. Carbonic anhydrase inhibitors. Inhibition of mammalian isoforms I-XIV with a series of natural product polyphenols and phenolic acids. Bioorg. Med. Chem. 2010, 18, 2159-2164.

[23] Zolnowska, B.; Slawiński, J.; Pogorzelska, A.; Chojnacki, J.; Vullo, D., Supuran, C. T. Carbonic anhydrase inhibitors. Synthesis, and molecular structure of novel series N-substituted N'-(2-arylmethylthio-4-chloro5-methylbenzenesulfonyl)guanidines and their inhibition of human cytosolic isozymes I and II and the transmembrane tumor-associated isozymes IX and XII Eur. J. Med. Chem. 2014, 71, 135-147.

[24] Öztürk Sarıkaya, S. B; Gülçin, İ.; Supuran C.T. Carbonic Anhydrase Inhibitors: Inhibition of Human Erythrocyte Isozymes I and II with a Series of Phenolic Acids. Chem. Biol. Drug. Des. 2010, 75, 515-520.

[25] Maresca, A.; Temperini, C.; Pochet, L.; Masereel, B.; Scozzafava, A.; Supuran C. T. Deciphering the Mechanism of Carbonic Anhydrase Inhibition with Coumarins and Thiocoumarins. J. Med. Chem. 2010, 53, 335-344.

[26] Moeker, J.; Peat, T. S.; Bornaghi, L. F.; Vullo, D.; Supupran, C. T.; Poulsen, S. A. Cyclic Secondary Sulfonamides: Unusually Good Inhibitors of Cancer-Related Carbonic Anhydrase Enzymes. J. Med. Chem. 2014, 57, 3522-3531.

[27] Di Fiore, A.; Maresca, A.; Alterio, V.; Supuran, C. T.; De Simone, G. Carbonic anhydrase inhibitors: X-ray crystallographic studies for the binding of $\mathrm{N}$-substituted benzenesulfonamides to human isoform II. Chem. Comm. 2011, 47, 11636-11638.

[28] Yıldırım, A., Atmaca, U., Keskin, A., Topal, M., Çelik, M., Gülçin, İ., Supuran, C.T. N-Acylsulfonamides strongly inhibit human carbonic anhydrase isoenzymes I and II. Bioorganic and Medicinal Chemistry 2015, 23(10), 2598-2605.

[29] Chen, H. -M.; Wu, Y. -C.; Chia, Y. -C.; Chang, F. -R.; Hsu, H. -K.; Hsieh, Y. -C.; Chen, C. -C; Yuan, S. $-\mathrm{S}$. Gallic acid, a major component of Toona sinensis leaf extracts, contains a ROS-mediated anti-cancer activity in human prostate cancer cells. Cancer Letters 2009, 286, 161-171.

[30] Hsu, C. -L.; Lo, W. -H.; Yen, G. -C. Gallic Acid Induces Apoptosis in 3T3-L1 Pre-adipocytes via a Fasand Mitochondrial-Mediated Pathway. J. Agric. Food Chem. 2007, 55, 7359-7365.

[31] Manuja, R.; Sachdeva, S.; Jain, A.; Chaudhary, J. A Comprehensive Review on Biological Activities of PHydroxy Benzoic Acid and Its Derivatives. Int. J. Pharm. Sci. Rev. Res. 2013, 22, 109-115. 
[32] Ye, J.; Abiman, P.; Crossley, A. Jones, J. H.; Wildgoose, G. G.; Compton, R. G. Building Block Syntheses of Gallic Acid Monomers and Tris-( $O$-gallyl)-gallic Acid Dendrimers Chemically Attached to Graphite Powder: A Comparative Study of Their Uptake of Al(III) Ions. Langmuir 2010, 26(3), 1776-1785.

[33] Wang, P.; Liu, C.; Sanches, T.; Zhong, Y.; Liu, B.; Xiong, J., Neamati, N.; Zhao, G. Bioorg. Med. Chem. Lett. 2009, 19, 4574-4578.

[34] Carroux, C. J.; Rankin, G. M.; Moeker, J.; Bornaghi, L. F.; Katneni, K.; Morizzi, J.; Charman, S. A.; Vullo, D. Supuran, C. T.; Poulsen, S. A. A Prodrug Approach Toward Cancer-Related Carbonic Anhydrase Inhibition. J. Med. Chem. 2013, 56, 9623-9634.

[35] Lu, Z.; Wei, S.; Huayu, W., Lin, X.; Lin, C.; Liu, B.; Zheng, L.; Zhao, J. A novel synthesized sulfonamidobased gallic acid-LDQN-C: Effects on chondrocytes growth and phenotype maintenance. Bioorganic Chemistry 2014, 57, 99-107.

[36] Zhang, X.-H.; Liu, L.-N.; Lin, Y.-J.; Lin, C.-W. Synthesis and interaction of bovine serum albumin with phydroxybenzoic acid derivatives. Luminescence 2013, 28, 419-426.

[37] Akıncıoğlu, A.; Akbaba, Y.; Göçer, H.; Göksu, S.; Gülçin, İ.; Supuran, C. T. Novel sulfamides as potential carbonic anhydrase isoenzymes inhibitors. Bioorg. Med. Chem. 2013, 21(6), 1379-1385.

[38] Nar, M.; Çetinkaya, Y.; Gülçin, İ.; Menzek, A. (3,4-Dihydroxyphenyl)(2,3,4-trihydroxyphenyl)methanone and its derivatives as carbonic anhydrase isoenzymes inhibitors. J. Enzyme Inhib. Med. Chem. 2013, 28, $402-406$

[39] Andrea-Marobela, K.; Ghislain, F. W.; Okatch, H.; Majinda, R. R. T. Polyphenols: A Diverse Class of Multi-Target Anti-HIV-1 Agents. Current Drug Metabolism. 2013, 14, 392-413.

[40] Daglia, M. Polyphenols as antimicrobial agents. Current Opinion in Biotechnology. 2012, 23, $174-181$.

[41] Laemmli, D.K. Cleavage of Structural Proteins during the Assembly of the Head of Bacteriophage T4 Nature 1970, 227, 680-685.

[42] Gülçin, İ.; Küfrevioğlu Ö.İ.; Oktay, M. Purification and characterization of polyphenol oxidase from nettle (Urtica dioica L.) and inhibitory effects of some chemicals on enzyme activity. J. Enzyme Inhib. Med. Chem. 2005, 20, 297-302.

[43] Verpoorte, J. A.; Mehta, S.; Edsall, J. T. Esterase activities of human carbonic anhydrases B and C. J. Biol. Chem. 1967, 242, 4221-4229.

[44] Bradford, M.M. A rapid and sensitive method for the quantitation of microgram quantities of protein utilizing the principle of protein-dye binding. Anal. Biochem. 1976, 72, 248-254.

[45] Boztaş, M., Çetinkaya, Y., Topal, M., Gülçin, İ., Menzek, A., Şahin, E., Tanc, M., Supuran, C.T. Synthesis and Carbonic Anhydrase Isoenzymes I, II, IX, and XII Inhibitory Effects of Dimethoxybromophenol Derivatives Incorporating Cyclopropane Moieties. J. Med. Chem. 2015, 58 (2), 640-650.

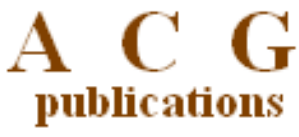

(C) 2017 ACG Publications 